\title{
ANTI-HELICOBACTER PYLORI ACTIVITY AND IMMUNOSTIMULATORY EFFECT OF OLIGOSACCHARIDE ISOLATED FROM AVERRHOA CARAMBOLA L.
}

\author{
KAPFO W ${ }^{1}$, CHAUHAN JB ${ }^{2 *}$ \\ ${ }^{1}$ Department of Biochemistry, PRIST University, Vallam, Tamil Nadu, India. ${ }^{2}$ Department of Biotechnology, Microbiology, Biochemistry and \\ Botany, Pooja Bhagavat Memorial Mahajana Education Centre, Metagalli, Mysuru, Karnataka, India. Email: jbchauhan2018@gmail.com
}

Received: 02 July 2018, Revised and Accepted: 05 October 2018

\section{ABSTRACT}

Objective: The main goals of the study were to isolate oligosaccharide as a secondary metabolite from indigenous fruit, Averrhoa carambola L. (star fruit), and analyze its anti-Helicobacter pylori and immunostimulatory potential.

Methods: The oligosaccharide (S3W) isolated using adsorption chromatography was partially characterized using tandem mass spectrometry in atmospheric pressure chemical ionization/electron spray ionization (APCI/ESI) positive and negative mode and nuclear magnetic resonance. The use of microtiter well method determined anti-H. pylori activity in the form of percentage inhibition of microbial growth, while the determination of the immunostimulatory potential of S3W implemented a protection of DNA, buccal cells, and macrophages against damage by oxidant and $\mathrm{N}$-nitroso-N- methylurea (MNU) and percentage splenocyte proliferative potential.

Results: S3W was a $(1 \rightarrow 2) \beta$-heptaglucosaccharide with $(4 \rightarrow 6) \alpha$-branching at every second residue. APCI/ESI-positive mode showed B and A fragmentation patterns, while the negative mode showed abundance of A and C fragments. Anomeric hydrogen displayed integration values at 4.8 and $4.2 \mathrm{ppm}$ indicating the presence of $\alpha$-glucopyranose and $\beta$-glucopyranose. The compound protected DNA from oxidant-induced fragmentation. It expressed anti- $H$. pyloric activity with an $\mathrm{IC}_{50}$ value of $10.71 \mu \mathrm{g} / \mathrm{ml}$. At $20 \mu \mathrm{g} / \mathrm{ml}$, S3W protected buccal cells and macrophages significantly from damage due to oxidants and MNU carcinogens, while $>50 \%$ splenocyte proliferation was induced as compared to that of an untreated control group.

Conclusion: Our studies constitute the first report on the significant immunostimulatory activity of the oligosaccharide isolated from star fruit. The study, thus, supports its application as a therapeutic potential in curbing gastric diseases caused by H. pylori.

Keywords: Helicobacter pylori, Macrophages, Splenocytes, Immunostimulation, Oligosaccharides.

(c) 2019 The Authors. Published by Innovare Academic Sciences Pvt Ltd. This is an open access article under the CC BY license (http://creativecommons. org/licenses/by/4. 0/) DOI: http://dx.doi.org/10.22159/ajpcr.2019.v12i2.28244

\section{INTRODUCTION}

The Gram-negative bacterium, Helicobacter pylori, can colonize in human gastric mucosa of an infected individual without causing clinical illness [1,2]. The development of gastric adenocarcinoma, gastric lymphoma, and mucosa-associated lymphoid tissue lymphoma in association with long-term $H$. pylori infection has classified H. pylori as a carcinogen [3-6]. It induces inflammation, reactive oxygen species (ROS) accumulation, infiltration and activation of immune cells, and oxidative damage to DNA in the gastric mucosa by protecting itself from death through instigating apoptosis to macrophages [2,7-9]. Its clinical manifestation is associated with factors such as host genetic factors, virulence factor of the bacteria, and its environment [10]. Hence, $H$. pylori on prolonged existence survives by manipulating the host immune response and creates a prosurvival and tolerant environment for itself which is harmful for the host. Treatment of H. pylori infection uses a combination of minimum two antibiotics and gastric acid inhibitors which often causes side effects such as nausea, antibiotic resistance, and recurrence [5]. The search for a safe and effective non- antibiotic agent has rekindled the interest in alternative medicine in the form of natural drugs. Herbal formulation or isolation of bioactive compounds is widely investigated, particularly in indigenous fruits known for their folkloric medicinal value [11]. Development of carbohydrates and carbohydrate-based molecules in drug discovery in the form of glycomics has attained increased recognition [12]. Recent advances in oligosaccharide research have established its application in therapy for areas such as inflammation, immunity, oncology, neurodegenerative diseases, and infection $[13,14]$. Synthetic oligosaccharides tested for its antibiotic potential against $H$. pylori were studied [15], while carbohydrates present in porcine milk were found to mediate prevention of $H$. pylori colonization [16]. However, substantial reports on the effect of oligosaccharides from plants against the bacteria are limited despite its antimicrobial potential. The challenge could be due to the natural oligosaccharides possessing diverse structural and size heterogeneity, challenging the ability to determine its detailed structure. Using biochemical tools such as chromatographic separations for isolation and characterization using spectral analysis such as mass spectra (MS) and nuclear magnetic resonance (NMR), drug discoveries have obtained success rates. Our study, thus, identifies the oligosaccharides isolated from star fruit and explores its potential as an anti-H. pyloric agent through immunostimulatory effects for the first time since the fruit is known to alleviate problems of the gut.

Starfruit (Averrhoa carambola L.) is a tree fruit with a distinctive star shape in cross-section. The edible fruit of the Oxalidaceae family is available locally in various products such as pickles, jam, or jelly. The powdered seed concoction of the fruit is traditionally used for its medicinal properties to treat hemorrhoids, fever, eczema, diarrhea, and asthma $[17,18]$. Extensive reports on the strong free radical scavenging potential of juice and residue of star fruit cultivated in Singapore and Indonesia have attributed its capacity to the rich procyanidin polymers and $\beta$-carotene [19]. Antioxidant and immunomodulatory effects of star fruit leaves were evidenced through increased antibody titer values and hematological profile in cyclophosphamide-induced immunosuppressed mice [20]. Our earlier reports established the antioxidant potential and anticancer properties of star fruit $[21,22]$. The present investigation is, therefore, the first to report the isolation of an oligosaccharide from star fruit (S3W) and its anti-H. pylori potential through its immunostimulatory ability. 


\section{METHODS}

\section{Plant material}

A. carambola fruit was procured from the local market of Mysore, Karnataka, during July-September. A herbarium specimen was deposited at the Herbarium Center, DOS in Botany, Manasagangothri, Mysuru (VS. No. DOSBWK05).

\section{Preparation of extract}

About $500 \mathrm{~g}$ of fresh fruit was blended and extracted with $1000 \mathrm{ml}$ of $60 \%$ acetone/water at $30^{\circ} \mathrm{C}$ for $3 \mathrm{~h}$ under continuous agitation and filtered using a muslin cloth. The residue was reextracted using $500 \mathrm{ml}$ of solvent mixture under the same conditions and the filtrates pooled. After concentration in a rotary evaporator (Buchi, Germany), the aqueous portion was dried in a hot-air oven at $50^{\circ} \mathrm{C}$.

\section{Isolation of star fruit oligosaccharide}

A sequence of biphase extraction on the aqueous extract of star fruit included using $10 \%$ ethyl acetate in methanol, $20 \%$ ethyl acetate in methanol, and $30 \%$ ethyl acetate in methanol, wherein the aqueous phase in each period of extraction was collected and subjected to further biphase separation. At $40 \%$ ethyl acetate in methanol, the obtained monophase was dried at $40^{\circ} \mathrm{C} .5 \mathrm{~g}$ of the dried extract was reconstituted in methanol and subjected to ethyl acetate equilibrated silica gel chromatography of $300 \mathrm{~mm} \times 10 \mathrm{~mm}$ column size using silica gel 60-120 mesh. A gradient of ethyl acetate: methanol (10:0, 8:2, 6:4, 4:6, 2:8, and 0:10) as mobile phase resulted in six fractions (S1-S6), of which fraction S3 was subjected to preparative thin-layer chromatography using the mobile phase ethyl acetate: methanol:water (1.65:9:1.35) and observed under UV. The blue fluorescing spot at Rf 0.63 (Supplementary material 1) was extracted using methanol and dried at $40^{\circ} \mathrm{C}$ to give $\mathrm{S} 3 \mathrm{~W}$. S3W underwent analysis by phenol- sulfuric acid method to confirm the presence of carbohydrates [23] and was further subjected to liquid chromatography -electron spray ionization (ESI)/atmospheric pressure chemical ionization (APCI)- MS/MS, and ${ }^{1} \mathrm{H}$ and ${ }^{13} \mathrm{C}$ NMR

High-performance liquid chromatography (HPLC)-ESI-mass spectrometry (ESI-MS) analyses of S3W

A BDS HYPERSIL C-18 column $(150 \mathrm{~mm} \times 4.6 \mathrm{~mm}, 5 \mu \mathrm{m}$ particle size) equipped with PDA/UV detector with $280 \mathrm{~nm}$ as the detecting wavelength was used for chromatographic separations in room temperature $\left(27^{\circ} \mathrm{C}\right)$ under the following conditions: $1 \mathrm{ml} / \mathrm{min}$; solvent $\mathrm{A}, 10 \%$ acetic acid in water; solvent $\mathrm{B}$, and $15 \%$ methanol in water starting from 0 to $20 \min (40-52 \% \mathrm{~A}), 20$ to $40 \mathrm{~min}(52-80 \% \mathrm{~A})$, and 40 to $60 \mathrm{~min}(80 \% \mathrm{~A})$.

The Synapt G2 HDMS ESI/APCI-Hybrid Quadrupole, Time-of-flight tandem mass spectrometer (Waters, USA) was used to identify S3W. The heated capillary and spray voltage were maintained at a temperature of $275^{\circ} \mathrm{C}$ and $4.5 \mathrm{kV}$. Nitrogen is operated at $40 \mathrm{psi}$ for sheath gas flow rate and 26 psi for auxiliary/sheath gas flow rate. The full scan MS from $\mathrm{m} / \mathrm{z}$ 50-2000 were acquired in positive and negative ion mode with a scan speed of $1 \mathrm{~s}$ per scan. The MS was performed using argon as collision gas, operated at 0.1 mtorr.

\section{NMR spectroscopy}

Proton and carbon NMR spectra were obtained using Agilent 400MR DD2 NMR spectrometer at $400 \mathrm{MHz}$. Sample dissolved in $700 \mu \mathrm{l}$ of dimethyl sulfoxide (DMSO)-d6 with concentration of 30 and $15 \mathrm{mg} / \mathrm{ml}$ for ${ }^{13} \mathrm{C}$ and ${ }^{1} \mathrm{H}$, respectively, was prepared and transferred to a $5 \mathrm{~mm}$ NMR tube, wherein the analysis was performed at $45^{\circ} \mathrm{C}$. The compound was identified by comparing spectra with that reported in literature $[24,25]$.

\section{Bacterial strains and cultivation}

H. pylori were isolated and confirmed as per the protocol of Belagihalli and Dharmesh [5].

\section{Inhibition of $\boldsymbol{H}$. pylori viable colony count method}

Bactericidal activity of the star fruit compound was determined using 96-well microtiter plate method [2]. $100 \mu \mathrm{l}$ suspension of
$10^{8}$ colony-forming units $/ \mathrm{ml}$ was treated with $100 \mu \mathrm{l}$ of distilled water (control) and S3W in concentration range of $2-10 \mu \mathrm{g} / \mathrm{ml}$ and absorbance read at $620 \mathrm{~nm}$ using an automatic ELISA microplate reader (Thermo Fisher, USA). The control consisted of $H$. pylori treated with sterile distilled water. The suspensions were incubated for 3 days at $37^{\circ} \mathrm{C}$ under microaerophilic atmosphere and the absorbance read again in the same wavelength after agitation. All experiments were performed 3 times. The absorbance obtained before and after incubation was compared, and percentage inhibition using the following formula was used.

$$
\text { Percentage inhibition }=1-\frac{\text { OD of test }}{\text { OD of control }}
$$

The effectiveness of S3W at killing H. pylori was expressed as percentage inhibition of bacterial growth (i.e., percentage of bacteria killed) compared to that of control.

\section{DNA protection assay}

DNA protection assay was conducted by the inhibition of Fenton's reagent induced strand breaks in lambda phage DNA by S3W [26]. The control group contained $5 \mu \mathrm{l}$ of phage DNA and $5 \mu$ l Fenton's reagent ( $30 \mathrm{mM} \mathrm{H} \mathrm{O}_{2}, 500 \mu \mathrm{M}$ ascorbic acid, and $800 \mu \mathrm{M}$ ferric chloride) made up to $25 \mu \mathrm{l}$ with distilled water, while the test group contained $5 \mu \mathrm{l}$ phage DNA and $5 \mu$ l Fenton's reagent followed by addition of $10 \mu \mathrm{l}$ of $1 \mathrm{mg} / \mathrm{ml}$ of S3W. The final volume was made up to $25 \mu \mathrm{l}$ with distilled water, and the reaction mixtures were incubated for $45 \mathrm{~min}$ at $37^{\circ} \mathrm{C}$. The strand break inhibition observed of test group was compared to that of control group using $0.9 \%$ agarose gel electrophoresis by staining with ethidium bromide.

\section{Buccal cell collection technique}

A clean toothpick full of cheek buccal cells from healthy consenting donors was agitated in $2 \mathrm{ml}$ cold phosphate buffer saline (PBS) $(100 \mathrm{mM}, \mathrm{pH} 7)$ and centrifuged at $2500 \mathrm{rpm}$ at $4^{\circ} \mathrm{C}$ for $10 \mathrm{~min}$. The supernatant was aspirated and the cell pellet resuspended in $100 \mu \mathrm{l}$ PBS.

Effect of S3W on buccal cells exposed to oxidant (ascorbic acid and $\mathrm{FeSO}_{4}$ ) and $\mathrm{N}$ - methyl N-nitrosourea (MNU)

To determine the effect of exposure of buccal cells to S3W in vitro, buccal cells were tested immediately after collection [27]. Buccal cells $\left(1 \times 10^{4}\right.$ cells/well) were exposed to $500 \mu \mathrm{M}$ ascorbic acid and $500 \mu \mathrm{M}$ $\mathrm{FeSO}_{4}$, and treated with and without $10 \mu \mathrm{g} / \mathrm{ml} \mathrm{S} 3 \mathrm{~W}$ for $1 \mathrm{~h}$ at $37^{\circ} \mathrm{C}$. Similarly, another set of buccal cells was treated with a carcinogen MNU $\left(10 \mu \mathrm{g} / \mathrm{ml}\right.$ for $1 \times 10^{4}$ cells/well $)$ and exposed to the presence and absence of 10 and $20 \mu \mathrm{g} / \mathrm{ml} \mathrm{S} 3 \mathrm{~W}$ for $1 \mathrm{~h}$ at $37^{\circ} \mathrm{C} .1 \mu \mathrm{l}$ of dye mix containing acridine orange and ethidium bromide of $100 \mu \mathrm{g} / \mathrm{ml}$ each was mixed to $25 \mu \mathrm{l}$ cell suspension of treated and untreated cells. They were observed under the fluorescence microscope at $\times 40$ (Olympus). Staining pattern between the cells was compared and cytoprotective ability of S3W was determined.

\section{Animals}

Experiments were performed using 6-8 weeks old Swiss albino mice, weighing 20-25 g. Animals were maintained in accordance with the OECD guidelines, and experiments were performed with the regulations of Farooqia College of Pharmacy, Mysuru, India (FCP/ EC- 5/273/2014- 2015).

\section{Isolation of peritoneal macrophages and cell culture}

Macrophages were isolated by peritoneal lavage from male Swiss albino mice [2]. The peritoneal cavity was washed with ice cold PBS supplemented with $20 \mathrm{U} / \mathrm{ml}$ heparin and $1 \mathrm{nM}$ EDTA. Care was taken not to cause internal bleeding while collecting macrophages in the exudates. The cells were cultured in $60 \mathrm{~mm}$ Petri dishes in RPM1640 media supplemented with $10 \% \mathrm{FBS}, 50 \mu \mathrm{g} / \mathrm{ml}$ penstrap for $24 \mathrm{~h}$ at $37^{\circ} \mathrm{C}$ in a humidified atmosphere of $5 \% \mathrm{CO}_{2}$ in $\mathrm{CO}_{2}$ incubator. Non-adherent cells were removed by vigorously washing 3 times with ice-cold PBS. Cell viability was evaluated by trypan blue exclusion and viable cells not 
$<95 \%$ was used for further studies. The Petri dishes containing the cells were divided into the following groups:

- Group I: Untreated cells (control)

- Group II: Cells treated with oxidant (ascorbic acid with $\mathrm{FeSO}_{4}$ )

- Group III: Cells treated with MNU

- Group IV: Cells treated with oxidant $+20 \mu \mathrm{g} / \mathrm{ml} \mathrm{S3W}$

- Group V: Cells treated with MNU + $10 \mu \mathrm{g} / \mathrm{ml} \mathrm{S3W}$

- Group VI: Cells treated with MNU + $20 \mu \mathrm{g} / \mathrm{ml} \mathrm{S3W}$

The cells were stained with a mixture of acridine orange and ethidium bromide dye and morphologically analyzed under fluorescence microscope. The protocol described was in accordance to that reported by Mahapatra et al. with slight modifications [27].

\section{Splenocyte proliferation assay}

Effect of S3W on splenocyte proliferation was tested by MTT assay [28] wherein splenocyte suspension $\left(1 \times 10^{6}\right.$ cells $\left./ \mathrm{ml}\right)$ in complete RPMI 1640 medium was incubated in different concentrations of S3W $(0-10 \mu \mathrm{g} / \mathrm{ml})$ dissolved in $0.1 \%$ DMSO in PBS. Control splenocytes include those treated with $0.1 \%$ DMSO in PBS only. After incubation for $48 \mathrm{~h}$ at $37^{\circ} \mathrm{C}$ in $5 \% \mathrm{CO}_{2}$ humidified atmosphere, the medium was removed and the adherent splenocytes were washed twice with PBS. $15 \mu \mathrm{L}$ of MTT stock solution ( $5 \mathrm{mg} / \mathrm{ml}$ ) was added to the culture medium for $4 \mathrm{~h}$ at $37^{\circ} \mathrm{C}$. Absorbance was measured at $450 \mathrm{~nm}$ using microplate reader. Percentage splenocyte proliferation was calculated using the following formula:

$$
\text { Percentage proliferation=1- } \frac{\text { OD before incubation }}{\text { OD after incubation }}
$$

Statistical analysis

The assays were conducted in triplicates and data are represented as mean \pm standard deviation. All statistical analysis was conducted using Origin 5.0

\section{RESULTS}

Anti-H. pylori activity of S3W

Inhibitory potential of S3W against $H$. pylori growth analyzed by bacterial growth inhibition method is shown in Fig. 1. S3W expressed an $\mathrm{IC}_{50}$ value of $10.71 \mu \mathrm{g} / \mathrm{ml}$.

\section{DNA damage protection assay}

DNA damage occurs through Fenton reaction generated by oxidants and carcinogens causing increase of its mobility in electrophoresis. Retardation of the S3W-treated DNA indicated that S3W recovered DNA from damage by the hydroxyl radicals (Fig. 2).

Protection of buccal cells from ascorbic acid/FeSO ${ }_{4}$ oxidant and MNU carcinogen damage

The cytoprotectivity on buccal cells treated with oxidant and MNU carcinogen is indicated in Fig. 3a-d. Intact viable cells stained green as they were bound more effectively by acridine orange than by ethidium bromide from the acridine orange/ ethidium bromide dye mixture whereas nuclear components of damaged cells stained more orange due to better interaction with ethidium bromide than to acridine orange. The oxidant and carcinogen induced clustering, cell disruption, and echnocytic type morphological alteration, whereas cells treated with S3W were normal indicating protection. Our results showed S3W-alleviated oxidative stress and protected the cells from undergoing cell damage.

Protection of peritoneal macrophages against oxidant (FeSO ${ }_{4}+$ ascorbic acid) and $\mathrm{MNU}$ carcinogen damage

Macrophage cellular damage was caused by oxidation induced by ROS generated by $\mathrm{FeSO}_{4}$ and ascorbic acid and reactive nitrogen species (RNS) generated by MNU (Fig. 4b and d). Cellular damage was first evident by fragmented nucleus followed by degraded cytoplasm and membrane deregulation. These distinctive characters implicated that the oxidants induced apoptosis. Results show that treatment of macrophages with S3W protected the macrophages exposed to

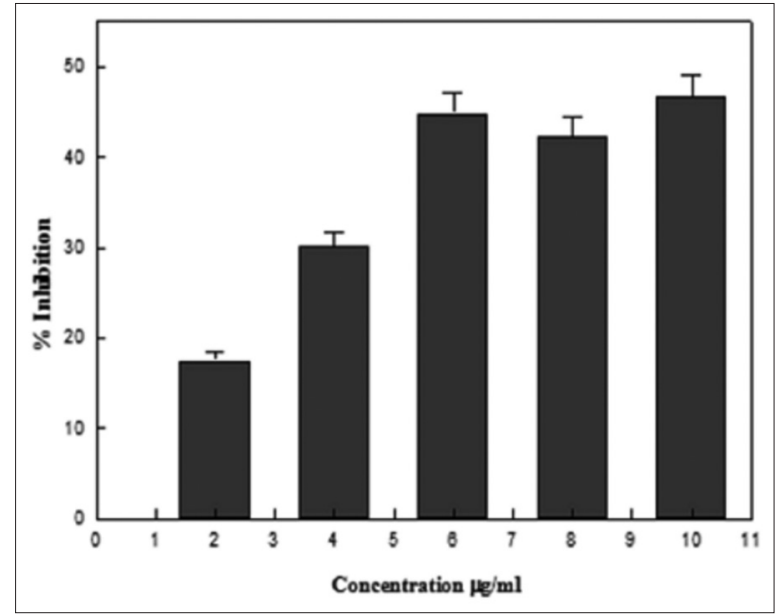

Fig. 1: Anti-Helicobacter pylori activity of $S 3 \mathrm{~W}$ is expressed as percentage inhibition wherein its IC $_{50}$ value is $10.7 \pm 0.192 \mu \mathrm{g} / \mathrm{ml}$ $(n=4)$

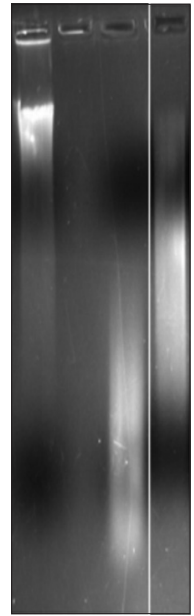

Fig. 2: Protection against DNA damage by S3W
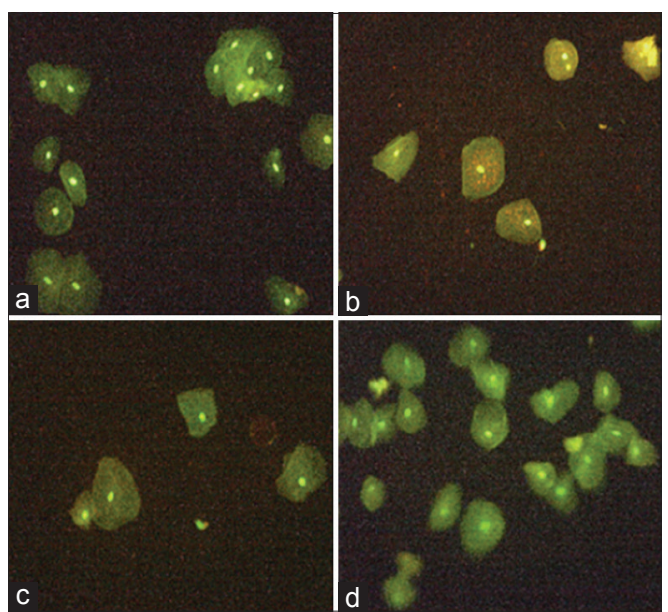

Fig. 3: Fluorescent microscopic view of buccal cells protected $\mathrm{N}$-nitroso-N-methylurea (MNU). (a) Control (b) buccal cells treated with MNU (c) buccal cells treated with $10 \mu \mathrm{g} / \mathrm{ml} \mathrm{S3W}$ (d) buccal cells treated with $20 \mu \mathrm{g} / \mathrm{ml} \mathrm{S3W}$

the oxidants and MNU from entering apoptosis (Fig. 4c, e, and f) by retaining the morphology of normal cell (Fig. 4a). Once again, S3W at $20 \mu \mathrm{g} / \mathrm{ml}$ showed better macrophage protective effect against MNU carcinogen. 
Immunostimulatory activity as evaluated by proliferation of splenocytes by MTT assay

The star fruit oligosaccharide induced significant immunostimulatory activity indicated by a distinct splenocyte proliferation increase. The proliferation was dose dependent, wherein splenocyte proliferated by 37 and $55.7 \%$ at 10 and $20 \mu \mathrm{g} / \mathrm{ml}$ concentration of S3W, respectively (Fig. 5). The resultant expression showed that S3W could be a potential mitogen.

\section{Liquid chromatography-MS of star fruit oligosaccharide}

The carbohydrate eluted at 2.574 min (Fig. 6a). The MS/MS spectra of isolated oligosaccharide generated by collision-induced dissociation (CID) were evaluated by assigning all product ions using the DomonCostello nomenclature [29]. Fig. 6b and c shows $\mathrm{MS}^{2}$ spectra of protonated and deprotonated oligosaccharides. The pattern of fragmentation indicated that the oligosaccharide was a low molecular weight sugar having 0-2 linkages at the first and second residues with possible branching at C-4. Protonated oligosaccharides are prone to cleaving exclusively at glycosidic bonds [30]. However, due to prolonged exposure to higher voltage, the oligomer underwent cross-ring cleavage along with the expected glycosidic linkages. The protonated oligosaccharide displayed mass of $\mathrm{m} / \mathrm{z}$ 1465. S3W (Fig. 6b) showed non-reducing $B_{1}$ and $B_{2}$ glycosidic cleavages at m/z 1303 and 978

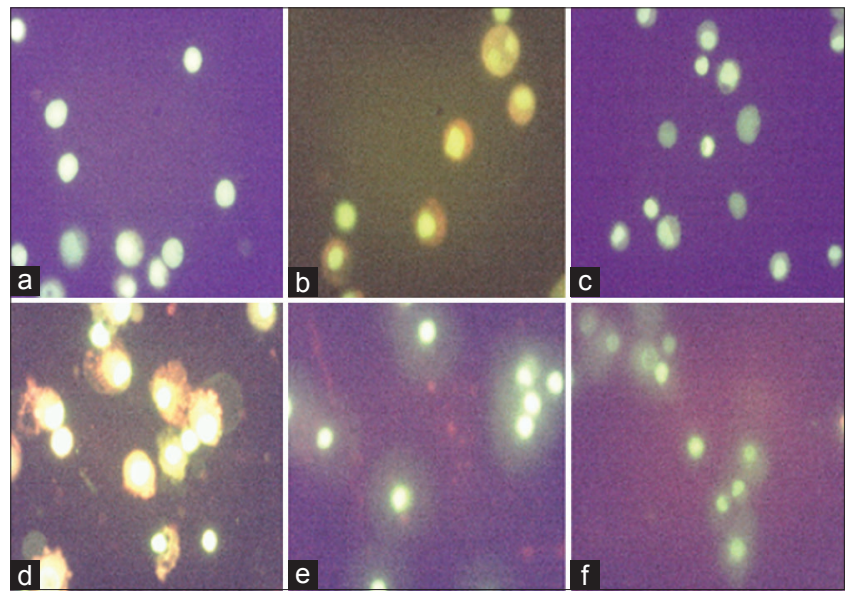

Fig. 4: Fluorescent microscopic view of macrophages protected against oxidant and $\mathrm{N}$-nitroso- $\mathrm{N}$-methylurea (MNU) (a) Control (b) macrophages treated with oxidant $\left(\mathrm{FeSO}_{4}+\right.$ ascorbic acid) (c) macrophages treated with $20 \mu \mathrm{g} / \mathrm{ml} \mathrm{S3W}$ (d) macrophages treated with MNU carcinogen (e) macrophages treated with $10 \mu \mathrm{g} / \mathrm{ml} \mathrm{S3W}$ (f) macrophages treated with $20 \mu \mathrm{g} / \mathrm{ml} \mathrm{S3W}$

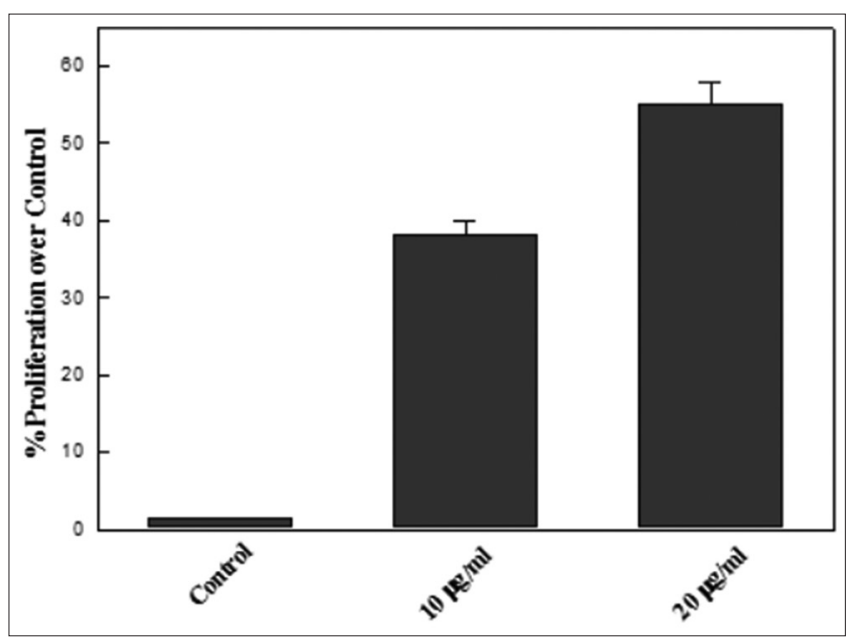

Fig. 5: Percentage proliferation of splenocytes treated with S3W as an indicator of immunostimulatory effect of $S 3 W(n=4)$ involving homolytic cleavage at $(1 \rightarrow 2) \beta$ - linkage bonds to release single glucose residue without the glycosidic oxygen at non-reducing terminal of backbone chain of $\mathrm{m} / \mathrm{z} 162$ and one $(1 \rightarrow 2) \beta$-linked backbone glucose residue connected by a $(4 \rightarrow 6) \alpha$ linkage. This accounted for mass loss of $\mathrm{m} / \mathrm{z} 325$. High-energy CID produced reducing fragmentation due to ${ }^{0,2} \mathrm{~A}_{3}$ and ${ }^{0,2} \mathrm{~A}_{4}$ cleavage which generated fragment ions at $\mathrm{m} / \mathrm{z} 853$ and 669 , respectively. A unique feature of the MS was observation of a series of A-type cross-ring cleavages and C-type cleavage (Fig. 6b) bearing fragment ions of $\mathrm{m} / \mathrm{z} 44$ of varying relative intensities from $\mathrm{m} / \mathrm{z} 405$ to $\mathrm{m} / \mathrm{z} 669$. The formation of the fragment ions at $\mathrm{m} / \mathrm{z} 44$ was possibly due to the $\mathrm{OH}$ or $-\mathrm{CH}_{2} \mathrm{OH}$ group of the precursor ion being on the same ring carbons adjacent to the ring oxygen. Cross-link cleavages are frequently seen at reducing side of sugars [30]. Further, fragmentation led to the release of ions at $\mathrm{m} / \mathrm{z} 388$ and 361 due to the loss of $-\mathrm{CHCH}_{2} \mathrm{OH}$ releasing non- reducing terminal glucose of side chain and reducing terminal of glucose backbone of m/z 180 each.

Fig. 6c shows the deprotonated MS of the oligosaccharide. According to Domon and Costello nomenclature, a series of A and C type fragments ions are expected in MS at negative mode [31]. Hence, fragmentation could have started from the non-reducing end of the oligosaccharide. The spectrum contained ${ }^{1,5} \mathrm{~A}_{1}$ and C- type fragmentation to release $\mathrm{m} / \mathrm{z}$ 1331 and 1295 although the molecular ion peak of m/z 1475 was not detected. ${ }^{1,5} \mathrm{~A}_{1 \alpha^{\prime}} \mathrm{C}_{2}$, and ${ }^{1,5} \mathrm{~A}_{4}$ fragmentation released fragment ions at $\mathrm{m} / \mathrm{z} 1007,971$, and 683 , respectively. The glucose backbone continued through a series of A- and C-type cleavage releasing ions of $\mathrm{m} / \mathrm{z} 359$, 323, and 215 (Fig 6c). The fragmentation pattern in negative mode was a characteristic of a $(1 \rightarrow 2) \beta$-linked saccharide with alternating $(4 \rightarrow 6)$ $\alpha$-branching.

\section{NMR spectroscopy of S3W}

From information of coupling constant (Supplementary material 2) at $8 \mathrm{~Hz}$ and $3.6 \mathrm{~Hz}, 4.231 \mathrm{ppm}$ was assigned for $\beta$-D-glucose and 4.883 to $\alpha$-D-glucose. The resonances of one of the methylene protons of the branch point glycosyl repeat unit at $3.225 \mathrm{ppm}$ were similar to that of integrated area of the anomeric proton suggesting a singly branched side chain of $(4 \rightarrow 6) \alpha$-linkages. The ratio of the areas from resonances assigned to $\mathrm{H} 1$ of side chain residue at and $\mathrm{H} 1$ of the $(1 \rightarrow 2) \beta$-linked repeat units in the polymer indicated that the side chain attached to the backbone on average every two repeat units. Coupling constant of $11.2 \mathrm{~Hz}$ at $4.161 \mathrm{ppm}$ was assigned to $3 \mathrm{~J}_{\mathrm{H2}-\mathrm{H} 3} .92 .630 \mathrm{ppm}$ was assigned to $\alpha$-C-1 of $(4 \rightarrow 6)$ - $\alpha$ side chain (SC) and 97.281 to $\beta$ - C-1 of reducing terminal (RT) of $(1 \rightarrow 2)$ - $\beta$-glycosyl backbone. $104.591 \mathrm{ppm}$ was assigned to $\beta-\mathrm{C}-1$ of non- reducing terminal, while $102.389 \mathrm{ppm}$ was assigned to $\beta$ - C-1 of internal residues. The presence of $(1 \rightarrow 2)-\beta$-bonding was evident by the presence of resonance at 81.444 to $83.751 \mathrm{ppm}$ for C-2 at the reducing terminals, while resonance at $75.253 \mathrm{ppm}$ was assigned to $\mathrm{C}-2$ of non-reducing terminal. Single branching at $(4 \rightarrow 6)-\alpha$ produced C-4 resonance at 77.096 to 77.156 ppm and C-6 resonance at 69.279 $69.302 \mathrm{ppm}$. Unsubstituted C-4 resonated at 70.334-71.010 ppm, while that by C- 6 at $61.653-63.712 \mathrm{ppm}$. The rest of the proton and carbon NMR assignments are summarized in Table 1

The resonance and MS analysis agreed with each other indicating the oligosaccharide likely to possess a $(1 \rightarrow 2) \beta$-linked heptasaccharide backbone with alternating $(4 \rightarrow 6) \alpha$-linked glycosyl branches (Fig. 7)

\section{DISCUSSION}

Glycobiologists have stated the wide scope for the applications of novel carbohydrate-based drugs particularly that of oligosaccharides to modulate the immune system since native polysaccharides and glycoconjugates have their large size (MW 10-1000 kDa) as one of the limitations for their value in drug discovery. Oligosaccharide as a secondary metabolite from star fruit was isolated using adsorption methods and partially characterized for the first time. Separation of carbohydrates is extensively carried out using high-pressure liquid chromatography while MS is a widely used tool to study its structure [31]. ESI is one of the common methods for carbohydrate analysis. However, the hydrophilicity of carbohydrates decreases its ionization efficiency, 


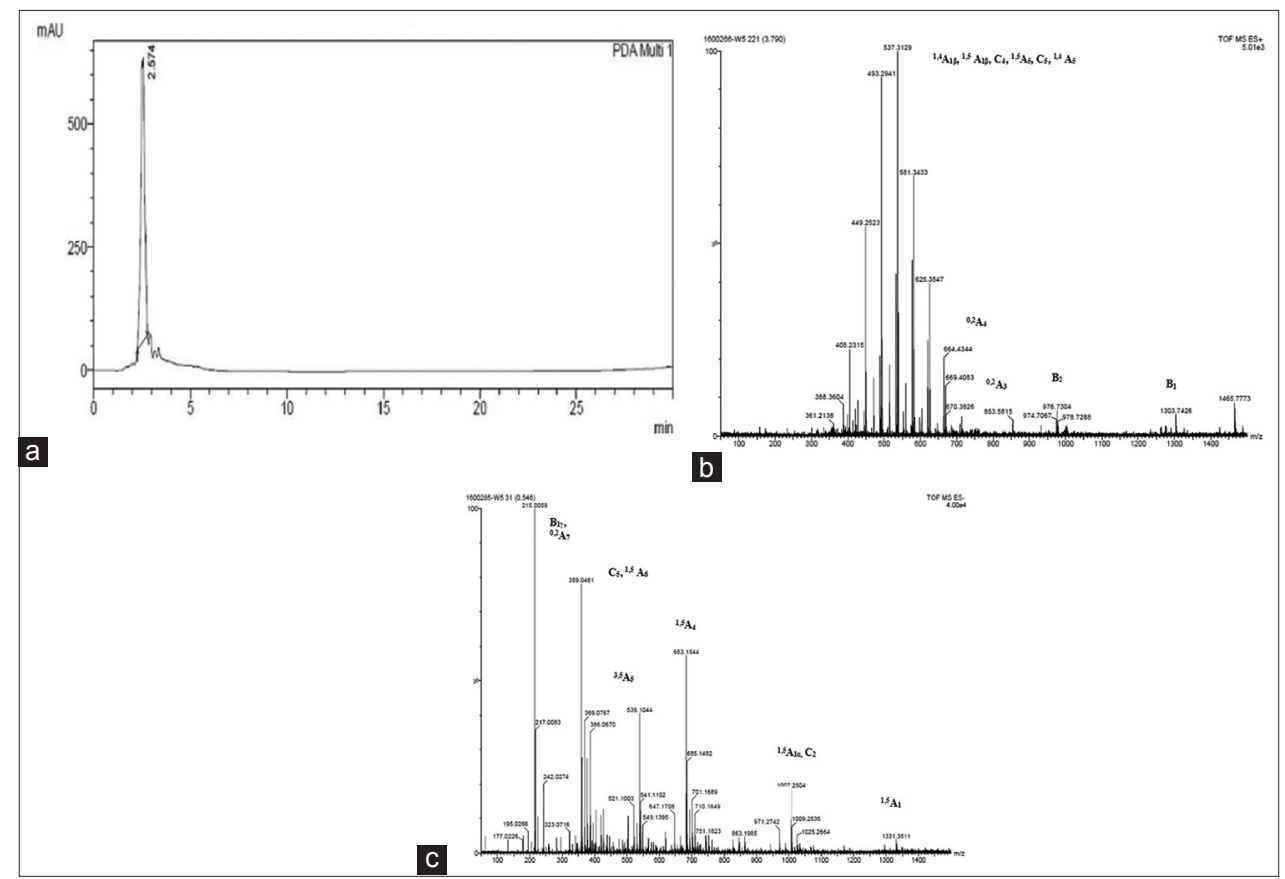

Fig. 6: High-performance liquid chromatography (HPLC)-electrospray ionization-mass spectrometry of S3W (a) HPLC chromatogram of S3W (b) MS/MS of protonated S3W (b) deprotonated S3W

Table 1: Chemical shifts ${ }^{1} \mathrm{H}$ and ${ }^{13} \mathrm{C}$ NMR spectroscopy assigned for S3W

\begin{tabular}{|c|c|c|c|c|c|}
\hline \multicolumn{6}{|c|}{ Chemical shift ppm } \\
\hline $\begin{array}{l}\text { Proton } \\
\text { assignment }\end{array}$ & $\begin{array}{l}(1 \rightarrow 2) \text { - } \beta \text {-linked } \\
\text { backbone chain }\end{array}$ & $\begin{array}{l}(1 \rightarrow 2)-\alpha \text { - } \beta \text {-linked } \\
\text { NRT }\end{array}$ & $\begin{array}{l}(1 \rightarrow 2) \\
\beta \text { - linked RT }\end{array}$ & $(4 \rightarrow 6)-\alpha-\mathrm{Br}$ & SC1 \\
\hline H1 & 4.251 & 4.251 & 4.231 & 4.251 & 4.883 \\
\hline $\mathrm{H} 2$ & 3.509 & 3.249 & 3.257 & 3.089 & 3.662 \\
\hline H3 & 3.613 & 3.418 & 3.407 & 3.706 & 3.113 \\
\hline $\mathrm{H} 4$ & 3.348 & 3.348 & 3.367 & 3.798 & 3.089 \\
\hline H5 & 3.638 & 3. 377 & 3.367 & 3.798 & 3.349 \\
\hline H6 & 3.787 & 3.798 & 3.787 & 4.131 & 4.133 \\
\hline H6 & 3.662 & 3.613 & 3.638 & 3.613 & 3.688 \\
\hline C1 & 102.389 & 104.597 & 97.281 & 101.569 & 92.630 \\
\hline $\mathrm{C} 2$ & 83.751 & 75.253 & 82.294 & 71.010 & 72.762 \\
\hline C3 & 77.096 & 77.096 & 77.096 & 83.751 & 73.521 \\
\hline $\mathrm{C} 4$ & 70.334 & 71.010 & 71.010 & 77.156 & 71.010 \\
\hline C5 & 77.156 & 78.416 & 77.156 & 75.775 & 75.258 \\
\hline C6 & 63.299 & 61.653 & 64.817 & 69.848 & 63.482 \\
\hline
\end{tabular}

particularly in increasing molecular weight [32]. Hence, an APCI/ ESI hybrid was used to improve the efficiency of the ionization of the oligosaccharide. Substantial use of MS for determining carbohydrate structure using the nomenclature of Domon and Costello has been recorded [33-37], wherein CID on carbohydrates produces distinct CID fragmentation explaining the linkage type and anomeric configuration. This, along with ESI to ionize oligosaccharides connected to tandem MS (MS/MS), is useful tool to elucidate carbohydrate structure. Protonated oligosaccharide cleavage generally occurs at the non-reducing side of the glycosidic oxygen (B- and Z-type). In negative mode, fragmentation patterns with C-and A-type ions are more common [25] compared to B-type fragments. The cross-link cleavages exposed the type of linkage present in the oligo/polysaccharides. The isolated oligosaccharide in negative mode fragmented into distinctive ions of mass $\mathrm{m} / \mathrm{z} 108,215$, and 195 which characterized the underivatized oligosaccharide as to possess a $\beta(1 \rightarrow 2)$ glycosidic linkage despite formation of abundant internal fragments. NMR is the most efficient technique to structurally analyze glycans [32]. It provides most of the experimental data to determine glycosidic linkages of carbohydrates from natural sources. In ${ }^{1} \mathrm{H}$ NMR spectroscopy, the anomeric protons are generally located at 4.2-5.8 ppm, while ring protons are found in the $3.2-4.5 \mathrm{ppm}$ region. The large ${ }^{13} \mathrm{C}$ chemical shift differences due to conformational and configurational changes made ${ }^{13} \mathrm{C}$ NMR spectroscopy a useful instrument to elucidate structures of star fruit oligosaccharides. Carbons involved in glycosylation exhibit a large downfield shift of approximately 4-10 ppm [38]. Slight upfield shifts at C3, C4, and C5 of $0.5 \sim 2 \mathrm{ppm}$ due to the $\beta$-effect of $1 \rightarrow 2$ linkage were evident. Downfield shifts of $7-8 \mathrm{ppm}$ indicated the $\beta(4 \rightarrow 6)$ linkage of the side chain. Based on comparison with resonances reported for $\beta(1 \rightarrow 2)$ glucans, distinctive shifts for ${ }^{13} \mathrm{C}$ and ${ }^{1} \mathrm{H}$ were assigned [24]. The results were in agreement with that reported. Characteristic resonance for anomeric carbon and hydrogen revealed the oligosaccharide to be a $\beta$ $(1 \rightarrow 2)$-linked glycan with $\alpha(4 \rightarrow 6)$ branching. It is, however, essential to employ 2D NMR analysis to completely elucidate the oligosaccharide.

Macrophages are critical components in immunity as they interact with T cells, B cells, natural killer cells, dendritic cells, neutrophils, and fibroblasts to phagocytize microorganisms in an attempt to kill them using ROS/RNS. Buccal cells, on the other hand, are the first barriers during inhalation or ingestion route, capable of metabolizing proximate carcinogens to reactive products, thus representing a preferred 


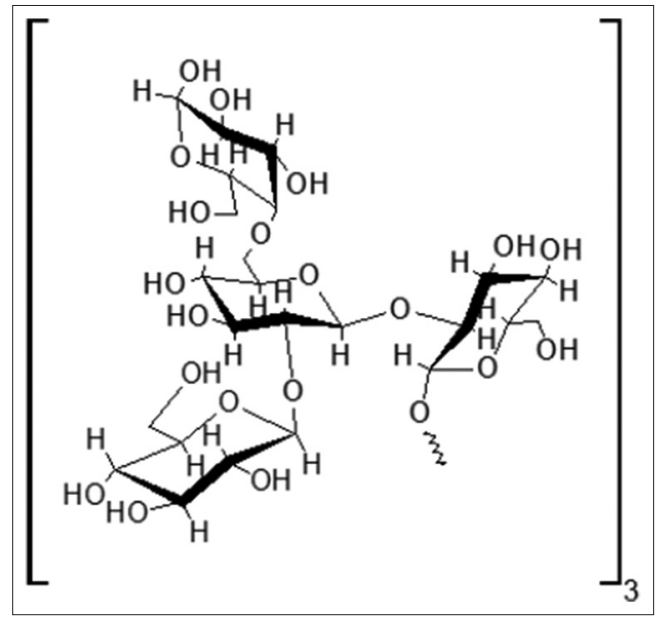

Fig. 7: Proposed structure of S3W

target site for early genotoxic events induced by carcinogens $[39,40]$. Eradication of $H$. pylori is strongly recommended to overcome gastric diseases such as gastric cancers as it plays the predominant role of being the main etiological agent for these gastric disorders. H. pylori hampers immunostimulation for its survival and causes the overproduction of ROS and RNS which itself harms host cells such as marcophages, neutrophils, and splenocytes [2]. Studies have suggested that such selfharm could be mainly due to ROS being able to eliminate any bacteria within the vicinity of the phagocyte, but separation between the phagocytes and the bacteria in the lumen curbs efficient elimination of H. pylori [3]. As a result, excess production of ROS and RNS damages DNA beyond its repair capabilities. This prolonged combined damage can also initiate the process of carcinogenesis. The therapeutic compounds are thus required to bear properties that enhance immunostimulatory effects and prevent progressive tumorogenesis. Kojima et al. observed that carbohydrate carriers reduced the affinity of $H$. pylori adhesion to antigens on gastric mucosa [41] which might explain the limitations of using carbohydrates as anti- $H$. pylori agents. The in vitro studies of the effect of star fruit glycan, however, showed promising potential. S3W was highly potent against $H$. pylori proliferation and its mechanism can be attributed to its anti-radical and immunostimulatory properties. Macrophages exposed to oxidants and MNU, a carcinogen most notably to cause adenocarcinoma of the stomach [42], were protected by S3W from undergoing damage significantly. Enhancement of phagocyte function is an established therapeutic application against microbial infection and cancer. Carbohydrates isolated from various medicinal plants possessed ability to regulate macrophage function resulting from its immune-stimulating activity $[43,44]$. $\beta$-glucans are postulated to act as pathogen-associated molecular pattern (PAMP) which binds to typical macrophages and dendritic cell surface receptors called pattern recognition receptors (PRRs) that detect innately non-self-molecules such as PAMPs. On binding, the PRRs can induce cascade of signals activating immune cells [45]. Thus, the ability of S3W to behave as a PAMP can be analyzed in future studies. Spleen as a blood filter responds to systemic infection by trapping blood born antigens wherein splenocytes in coordination with $\mathrm{B}$ and $\mathrm{T}$ lymphocytes help in pathogen clearance in the body primarily through antibody formation and secretion. An increase in the concentration of splenocytes enhances acquired immunity and is an important criterion of immunostimulation [26]. Elaborate records of the effect of oligosaccharides such as nigerose oligosaccharides, asparagine-like oligosaccharides, synthetic $\beta(1 \rightarrow 6)$ branched $\beta(1 \rightarrow 3)$ gluco-hexose, fructooligosaccharides, chitosan oligosaccharides, and many more in augmentation of splenocyte proliferation resulting in its production of many cytokines such as interleukin-2 (IL-2), interferon- $\gamma$, IL-6, and tumor necrosis factor $\alpha$ are available [35,46-49]. There, however, are no substantial reports of immunomodulatory effect of $(1 \rightarrow 2) \alpha / \beta$ linked oligosaccharides. The present study is the first to reveal a star fruit oligosaccharide which is most probably $(1 \rightarrow 2)$ - $\beta$ - linked, expressing for the first time the significant mitogenic property evident by the enhanced splenocytes proliferation by more than $50 \%$ at $20 \mu \mathrm{g} / \mathrm{ml}$ compared to untreated splenocytes. To our knowledge, such significant reports of star fruit oligosaccharides have not been published elsewhere. It is evident that the use of oligosaccharides from natural sources for its anti- $H$. pylori potential, particularly, is in its infancy. There is a wide scope to extensively study and further establish oligosaccharides in drug discovery. Our investigation is the first to highlight the distinct potential of $(1 \rightarrow 2)-\beta,(4 \rightarrow 6)-\alpha$ linked oligosaccharide isolated from fruit of star fruit as an agent against gastric cancer caused by $H$. pylori through its immunomodulatory functions. Future studies are encouraged to analyze immune factors released as a result of immunomodulation by the star fruit oligosaccharide and establish the molecular mechanism.

\section{CONCLUSION}

Star fruit oligosaccharide showed anti- $H$. pylori activity through immunomodulatory effects by protecting DNA from damage caused by free radicals, cytoprotection from carcinogen like MNU, and stimulating proliferation of splenocytes. The oligosaccharide has a therapeutic potential for application in immunotherapy. Further research to understand the molecular mechanism by which the oligosaccharide can protect and induce proliferation of immune cells to promote anti $H$. pylori activity is encouraged.

\section{ACKNOWLEDGMENT}

The authors thank the University Grants Commission, New Delhi, India, for their financial support (Project F.No. 37-519 (2009) SR), Director of Pooja Bhagavat Memorial Mahajana Education Centre, PG Wing of SBRR Mahajan First Grade College and Mahajana Education Society, Mysore, India, for providing the infrastructure for conducting the experiments, Dr. Shylaja M Dharmesh, CFTRI for her valuable guidance in conducting the bioassays, and Institute of Excellence, University of Mysore, Mysuru, for rendering their facilities to perform the spectral analysis. Wethroe Kapfo thanks the Council for Scientific and Industrial Research, Government of India for financial support as Senior Research Fellowship (08/6/6 (0001)/2014- EMR- I).

\section{AUTHORS' CONTRIBUTIONS}

Jyoti Bala Chauhan: Conceptualized and designed the experiments. She has guided in data analysis and edited the manuscript.

Wethroe Kapfo: performed the experiments, analyzed the data and prepared the manuscript.

\section{CONFLICT OF INTEREST}

The authors declare that there is no conflict of interest.

\section{REFERENCES}

1. Li H, Yang T, Liao T, Debowski AW, Nilsson HO, Haslam SM, et al. Insights from the redefinition of Helicobacter pylori lipopolysaccharide O-antigen and core-oligosaccharide domains. Microb Cell 2017:4:175-8

2. Bonacorsi C, Raddi MS, Carlos IZ, Sannomiya M, Vilegas W. Antihelicobacter pylori activity and immunostimulatory effect of extracts from Byrsonima crassa nied. (Malpighiaceae). BMC Complement Altern Med 2009;9:2.

3. Butcher LD, den Hartog G, Ernst PB, Crowe SE. Oxidative stress resulting from Helicobacter pylori infection contributes to gastric carcinogenesis. Cell Mol Gastroenterol Hepatol 2017;3:316-22.

4. Moss SF. The clinical evidence linking Helicobacter pylori to gastric cancer. Cell Mol Gastroenterol Hepatol 2017;3:183-91.

5. Belagihalli SM, Dharmesh SM. Anti-Helicobacter pylori, proton pump inhibitory and antioxidant properties of selected dietary/medicinal plants. Int J Phytomed 2012;4:573-81.

6. Parsonnet J, Hansen S, Rodriguez L, Gelb AB, Warnke RA, Jellum E, et al. Helicobacter pylori infection and gastric lymphoma. N Engl J Med 1994;330:1267-71. 
7. Handa O, Naito Y, Yoshikawa T. Helicobacter pylori: A ROS-inducing bacterial species in the stomach. Inflamm Res 2010;59:997-1003.

8. Bagchi D, McGinn TR, Ye X, Bagchi M, Krohn RL, Chatterjee A, et al. Helicobacter pylori-induced oxidative stress and DNA damage in a primary culture of human gastric mucosal cells. Dig Dis Sci 2002;47:1405-12.

9. Ashwini P, Sumana MN, Shilpa U, Mamatha P, Manasa P, Dhananjaya BL, et al. A review on Helicobacter pylori: Its biology, complications and management. Int J Pharm Pharm Sci 2015;7:14-20.

10. Omran R, Al-Naji HA, Al-Sherify A. Investigation of Helicobacter pylori virulence genotype in gastric biopsies by polymerase chain reaction. Asian J Pharm Clin Res 2016;9:106-14

11. Sharma $\mathrm{D}$, Bhatt $\mathrm{S}$. A comprehensive review on ulcer healing potential of medicinal plants. Int J Pharm Pharm Sci 2014;6:3-11

12. Turnbull JE, Field RA. Emerging glycomics technologies. Nat Chem Biol 2007;3:74-7.

13. Koeller KM, Wong $\mathrm{CH}$. Emerging themes in medicinal glycoscience. Nat Biotechnol 2000;18:835-41.

14. Dube DH, Bertozzi CR. Glycans in cancer and inflammation-potential for therapeutics and diagnostics. Nat Rev Drug Discov 2005;4:477-88.

15. Manabe S, Ishii K, Ito Y. Synthesis of a natural oligosaccharide antibiotic active against Helicobacter pylori. J Org Chem 2007;72:6107-15.

16. Gustafsson A, Hultberg A, Sjöström R, Kacskovics I, Breimer ME, Borén $\mathrm{T}$, et al. Carbohydrate-dependent inhibition of Helicobacter pylori colonization using porcine milk. Glycobiology 2006;16:1-0.

17. Corrêa AD. Medicinal Plants: From Cultivation to Therapy. Petrópolis: Editora Vozes; 2003. p. 6.

18. Carolino RO, Beleboni RO, Pizzo AB, Vecchio FD, Garcia-Cairasco N, Moyses-Neto $\mathrm{M}$, et al. Convulsant activity and neurochemical alterations induced by a fraction obtained from fruit Averrhoa carambola (Oxalidaceae: Geraniales). Neurochem Int 2005;46:523-31.

19. Shui G, Leong P. Residue from star fruit as valuable source for functional food ingredients and antioxidant nutraceuticals. Food Chem 2006;7:277-84.

20. Wahab S, Hussain A, Ahmad MP, Rizvil A, Ahmad MF, Farooqui AH. The ameliorative effects of Averroha carambola on humoral response to sheep erythrocytes in non-treated and cyclophosphamide immune compromised mice. J Acute Disease 2014;3:115-23.

21. Chauhan JB, Kapfo W. Effect of traditional sun drying on indigenous star fruit (Averrhoa carambola) from India. Int J Plant Anim Environ Sci 2016;6:121-32.

22. Chauhan JB, Kapfo W, Jayarama S, Balaji KS. Antiangiogenic and proapoptotic activity of Averrhoa carambola L. fruit extract on Ehrlich ascites carcinoma treated mice. Int J Appl Biol Pharm 2015;6:246-54.

23. Nowotny A. Carbohydrate determination by phenol-sulfuric acid. In: Basic Exercises in Immunochemistry. Berlin: Springer; 1979. p. 171-7.

24. Andre I, Mazeau K, Taravel FR, Tvaroska I. NMR and molecular modeling of sophorose and sophorotriose in solution. New J Chem 1995; 19:331-9.

25. Bruch MD. NMR Spectroscopy Techniques. $2^{\text {nd }}$ ed. New York: Marcel Dekker, Inc.; 1996.

26. Sudha ML, Dharmesh SM, Pynam H, Bhimangouder SV, Eipson SW, Somasundaram R, et al. Antioxidant and cyto/DNA protective properties of apple pomace enriched bakery products. J Food Sci Technol 2016;53:1909-18.

27. Mahapatra SK, Chakraborty SP, Das S, Roy S. Methanol extract of Ocimum gratissimum protects murine peritoneal macrophages from nicotine toxicity by decreasing free radical generation, lipid and protein damage and enhances antioxidant protection. Oxid Med Cell Longev 2009;2:222-30.

28. Talmale S, Bhujade A, Patil MB. Investigations into the immunostimulatory activities of the compounds isolated from Zizyphus Mauritiana. J Clin Cell Immunol 2015;6:5-11.
29. Tang H, Mechref Y, Novotny MV. Automated interpretation of MS/MS spectra of oligosaccharides. Bioinformatics 2005;21 Suppl 1:i431-9.

30. Lee S, Valentine SJ, Reilly JP, Clemmer DE. Analyzing a mixture of disaccharides by IMS-VUVPD-MS. Int J Mass Spectrom 2012;309:161-7.

31. Hsu HC, Liew CY, Huang SP, Tsai ST, Ni CK. Simple method for de novo structural determination of underivatised glucose oligosaccharides. Sci Rep 2018;8:5562.

32. Campestrini LH, Silveira JL, Duarte ME, Koop HS, Noseda MD. NMR and rheological study of Aloe barbadensis partially acetylated glucomannan. Carbohydr Polym 2013;94:511-9.

33. Tan Y, Polfer NC. Linkage and anomeric differentiation in trisaccharides by sequential fragmentation and variable-wavelength infrared photodissociation. J Am Soc Mass Spectrom 2015;26:359-68.

34. Shibata N, Kobayashi H, Okawa Y, Suzuki S. Existence of novel beta1,2 linkage-containing side chain in the mannan of Candida lusitaniae, antigenically related to Candida albicans serotype A. Eur J Biochem 2003;270:2565-75

35. Lundqvist L. Structural and Interaction Studies of Polysaccharides by NMR Spectroscopy. PhD Thesis. Uppsala: Swedish University of Agricultural Sciences; 2015.

36. Hofmeister GE, Zhou Z, Leary J. Linkage position determination in lithium-cationized disaccharides; tandem mass spectrometry and semiemperical calculations. J Am Chem Soc 1991;113:5964-70.

37. Asam MR, Glish GI. Tandem mass spectrometry of alkali cationized polysaccharides in a quadrapole ion trap. J Am Soc Mass Spectrom 1998;8:987-95.

38. Cheng HN, Neiss TG. Solution NMR spectroscopy of food polysaccharides. Polym Rev 2012;52:81-114

39. Weindl G, Wagener J, Schaller M. Epithelial cells and innate antifungal defense. J Dent Res 2010;89:666-75.

40. Hebecker B, Naglik JR, Hube B, Jacobsen ID. Pathogenicity mechanisms and host response during oral Candida albicans infections. Expert Rev Anti Infect Ther 2014;12:867-79.

41. Kojima N, Seino K, Sato Y, Mizuochi T. Carbohydrate carriers affect adhesion of $H$. Pylori to immobilized leb-oligosaccharide. FEBS Lett 2002;517:32-6.

42. Faustino-Rocha AI, Ferreira R, Oliveira PA, Gama A, Ginja M. $\mathrm{N}$-methyl-N-nitrosourea as a mammary carcinogenic agent. Tumour Biol 2015;36:9095-117.

43. Schepetkin IA, Quinn MT. Botanical polysaccharides: Macrophage immunomodulation and therapeutic potential. Int Immunopharmacol 2006;6:317-33.

44. Zhai X, Yang X, Zou P, Shao Y, Yuan S, Abd El-Aty AM, et al. Protective effect of chitosan oligosaccharides against cyclophosphamide-induced immunosuppression and irradiation injury in mice. J Food Sci 2018;83:535-42.

45. Kim HS, Hong JT, Kim Y, Han SB. Stimulatory effect of $\beta$-glucans on immune cells. Immune Netw 2011;11:191-5.

46. Kumar VP, Prashanth KV, Venkatesh YP. Structural analyses and immunomodulatory properties of fructo-oligosaccharides from onion (Allium cepa). Carbohydr Polym 2015;117:115-22.

47. Yan J, Zong H, Shen A, Chen S, Yin X, Shen X, et al. The beta- $(1 \rightarrow 6)-$ branched beta- $(1 \rightarrow 3)$ glucohexaose and its analogues containing an alpha- $(1 \rightarrow 3)$-linked bond have similar stimulatory effects on the mouse spleen as lentinan. Int Immunopharmacol 2003;3:1861-71.

48. Powell LD, Bause E, Legler G, Molyneux RJ, Hart GW. Influence of asparagine-linked oligosaccharides on tumor cell recognition in the mixed lymphocyte reaction. J Immunol 1985;135:714-24.

49. Murosaki S, Muroyama K, Yamamoto Y, Kusaka H, Liu T, Yoshikai Y, et al. Immunopotentiating activity of nigerooligosaccharides for the $\mathrm{T}$ helper 1-like immune response in mice. Biosci Biotechnol Biochem 1999;63:373-8. 